\title{
Kinetics and thermodynamic study of malachite green adsorption on seeds of dates
}

\author{
Khairia M. Al-Ahmary \\ Chemistry Department, Sciences Faculty for Girls, King Abdul-Aziz University, Jeddah, Kingdom of Saudi Arabia \\ E-mail: khairiaalahmary@yahoo.com
}

\begin{abstract}
This study reports the adsorption of malachite green (MG) dye by Seeds of Dates (SD) from solution. Batch adsorption of MG was conducted to evaluate the effect of initial $\mathrm{pH}$, contact time, temperature, initial dye concentration, $\mathrm{SD}$ adsorbent dose, and removal of the adsorbate MG dye from aqueous solution to understand the mechanism of adsorption involved. Adsorption equilibrium reached rapidly with 96\% MG removal in 120 min. Fit of the adsorption experimental data was tested on the pseudo-first and pseudo-second-order kinetics mathematical equations, which was noted to follow the pseudo-second-order kinetics better, with coefficient of correlation $\geq 0.992$. The equilibrium process was well described by the Freundlich isotherm model, with maximum adsorption capacity of $158.98 \mathrm{mg} \mathrm{g}^{-1}$. The study shows that SD has the potential of application as an efficient sorbent for the removal of MG from aqueous solutions.
\end{abstract}

Keywords: Adsorption, Malachite green, Seeds of dates, Kinetic, Thermodynamic

\section{Introduction}

Dyes have long been used in dyeing, paper and pulp, textiles, plastics, leather, cosmetics and food industries [1]. Colour stuff discharged from these industries poses certain hazards and environmental problems. These colored compounds are not only aesthetically displeasing but also inhibiting sunlight penetration into the water and affecting aquatic ecosystem [2]. Dyes usually have complex aromatic molecular structures which make them more stable and difficult to biodegrade. Furthermore, many dyes are toxic to some microorganisms and may cause direct destruction or inhibition of their catalytic capabilities [3,4]. With industrialization, the discharge of industrial wastewater has increased. At the same time, there are environmental concerns, and there is the need to find cheap and efficient methods for the treatment of industrial wastewater prior to disposal into natural waters [5-7]. Adsorption method can remove dyes steadily. In recent years, considerable attention has been paid on various adsorbents, such as activated bituminous coal [8], vetiver root activated carbon [9] activated carbon from oil palm wood [10], neem leaf powder [11], maize bran [12], crab shell [13], lemon peel [14] and eggshell [15].

Malachite green is an organic compound that is used as a dyestuff and has emerged as a controversial agent in aquaculture. Malachite green is traditionally used as a dye for materials such as silk, leather, and paper.

The objective of this work was to study the feasibility of using Seeds of Dates (SD) as an adsorbent for malachite green removal from solutions. In doing so, the adsorption of malachite green on SD from aqueous solutions was evaluated in batch experiments. The adsorption isotherms, kinetics and temperature effect were studies.

\section{Experimental}

\subsection{Material and methods}

\subsubsection{Preparation of Seeds of Dates}

Seeds of Dates (SD) were collected from local houses. To prevent decomposition, SD were washed in tap water, then the SD were boiled in distilled water, finally the SD were dried at $105^{\circ} \mathrm{C}$ in a hot oven for $2 \mathrm{~h}$. The dried SD were ground separately using a blender. The powdered materials were sieved to obtain particles with size $(0.2-0.4 \mathrm{~mm})$. 


\subsubsection{Preparation of dye solution}

Malachite green (MG) in commercial purity obtained from Fluka were used. A stock solution of $1000 \mathrm{mg} \mathrm{L}^{-1}$ of the dye was prepared by dissolving $1 \mathrm{~g}$ of dye in $1 \mathrm{~L}$ deionized water. The experimental solutions were obtained by diluting the dye stock solution in accurate proportion to different initial concentrations.

\subsection{Adsorption experiments}

The adsorption of MG dye on the SD was studied by batch technique. A known weight of adsorbent (100 - 500 mg) was equilibrated with $50 \mathrm{~mL}$ of dye solution of known concentration in a $150 \mathrm{~mL}$ Erlenmeyer flasks in a mechanical shaker at $150 \mathrm{rpm}$ for a known period of time $(5-180 \mathrm{~min})$. The effect of some parameters, such as pH, temperature, dosage of SD, contact time and dye concentrations was studied. The initial $\mathrm{pH}$ values of the solutions were previously adjusted with $\mathrm{HCl}(0.1 \mathrm{M})$ or $\mathrm{NaOH}(0.1 \mathrm{M})$ using METTLER TOLEDO MP230 pH Meter. At the end of adsorption tests, the suspensions were centrifuged for $5 \mathrm{~min}$ at $2000 \mathrm{xg}$ and the concentrations of residual dye were determined using UV-Visible spectrophotometer (Shimadzu UV- 1601 Ultraviolet - Visible Spectroscopy) corresponding to $\lambda_{\max }$ of dye $663.5 \mathrm{~nm}$. Blank solution with no dye was used for each series of experiments. Dilutions were carried out when measurement exceeded the linearity of the calibration curve. The results of these studies were used to obtain the optimum conditions for maximum dye removal from aqueous solution.

\section{Adsorption isotherms}

The amounts of adsorbed dye at equilibrium $\left(\mathrm{q}_{\mathrm{e}}\right)$ and the adsorption percentage of dye were calculated from the mass balance equations 1 and 2 respectively, as follows:

$$
\begin{aligned}
& q_{e}=\frac{\left(C_{i}-C_{e}\right) V}{W} \\
& \text { Adsorption }(\%)=\frac{C_{i}-C_{e}}{C_{i}} \times 100
\end{aligned}
$$

Where $\mathrm{C}_{\mathrm{i}}$ and $\mathrm{C}_{\mathrm{e}}\left(\mathrm{mg} \mathrm{L}^{-1}\right)$ are the initial and equilibrium concentrations of dye, respectively; $\mathrm{q}_{\mathrm{e}}\left(\mathrm{mg} \mathrm{g}^{-1}\right)$ is the equilibrium dye concentration on adsorbent; $\mathrm{V}(\mathrm{L})$ is the volume of dye solution and $\mathrm{W}(\mathrm{g})$ is the mass of dry adsorbent used.

\subsection{Reproducibility and data analysis}

Unless indicated otherwise, the data reported are the mean values of three separate experiments. The amount of dye adsorbed per unit SD (mg g ${ }^{-1}$ ) was determined as shown in Eq. (1). Langmuir [16], Freundlich [17] and LangmuirFreundlich [18] models. were used for the evaluation of adsorption data.

Langmuir isotherm assumes monolayer adsorption, which is presented by the equation:

$$
q_{e}=\frac{q_{\max } b C_{e}}{\left(1+b C_{e}\right)}
$$

where $\mathrm{q}_{\mathrm{e}}$ and $\mathrm{q}_{\max }$ are the equilibrium and maximum dye adsorption capacities $\left(\mathrm{mg} \mathrm{g}^{-1}\right.$ sorbent), respectively; $\mathrm{C}_{\mathrm{e}}$ the equilibrium dye concentration $\left(\mathrm{mg} \mathrm{L}^{-1}\right)$; and $\mathrm{b}$ the Langmuir equilibrium constant $\left(\mathrm{L} \mathrm{mg}^{-1}\right)$.

Freundlich model is presented as:

$$
q_{e}=K_{F} C_{e}^{1 / n}
$$

where $\mathrm{K}_{\mathrm{F}}$ and $\mathrm{n}$ are the Freundlich constants characteristic of the system.

Langmuir-Freundlich modle is presented as:

$$
q_{e}=\frac{q_{\max } C_{e}^{\beta}}{K+C_{e}^{\beta}}
$$


Where $\mathrm{K}$ is the saturation constant $\left(\mathrm{mg} \mathrm{L}^{-1}\right), \beta$ is the cooperative binding constant.

In order to investigate adsorption processes of adsorption MG on SD composite, the data obtained from adsorption kinetic experiments were simulated using two kinetic models. First; the pseudo-first-order rate equation of Lagergren $[19,20]$ is presented as:

$$
\ln \left(q_{e}-q_{t}\right)=\ln q_{e}-k_{1} t
$$

where $\mathrm{k}_{1}\left(\mathrm{~min}^{-1}\right)$ is the pseudo-first-order reaction rate constant.

The pseudo-first-order considers the rate of occupation of adsorption sites to be proportional to the number of unoccupied sites. A straight line of $\ln \left(\mathrm{q}_{\mathrm{e}}-\mathrm{q}_{\mathrm{t}}\right)$ versus $\mathrm{t}$ indicates the application of pseudo-first-order kinetics model. In a true pseudo-first-order process, $\ln \mathrm{q}_{\mathrm{e}}$ should be equal to the intercept of a plot of $\ln \left(\mathrm{q}_{\mathrm{e}}-\mathrm{q}_{\mathrm{t}}\right)$ against $\mathrm{t}$.

Second: the pseudo-second-order equation [21], another equation used for kinetics analysis, which is based on the sorption equilibrium capacity, may be expressed in the following form:

$$
\frac{t}{q_{t}}=\frac{1}{k_{2} q_{e}^{2}}+\frac{1}{q_{e}} t
$$

where $\mathrm{k}_{2}$ is the pseudo-second-order rate equilibrium constant $\left(\mathrm{g} \mathrm{mg}^{-1} \mathrm{~min}^{-1}\right)$.

A plot of $\frac{t}{q_{t}}$ against $t$ should give a linear relationship for the applicability of the pseudo-second-order kinetics model.

All the model parameters were evaluated from a linear regression using the Sigma Plot (version 10.0, SPSS, USA) software.

The average percentage error between the experimental and predicted values was calculated using:

$$
\varepsilon(\%)=\frac{\sum_{i=1}^{N}\left(q_{\exp , i}-q_{c a l, i} / q_{\exp , i}\right)}{N} \times 100
$$

Where $\mathrm{q}_{\text {exp }}$ and $\mathrm{q}_{\mathrm{cal}}$ represent the experimental and calculated dye adsorption values, respectively, and $\mathrm{N}$ the number of measurements.

\section{Results and discussion}

\subsection{Effect of initial $\mathrm{pH}$}

The initial $\mathrm{pH}$ of an aqueous solution is an important factor in dye adsorption, as it affects the surface charge of the sorbent material and the degree of ionization of the dye molecule [22]. $\mathrm{pH}$ has been related with changes in the structural stability and color intensity of the dye molecule [23]. The removal of MG dye by SD over a range of 2-12 was noted to increase with the increase in $\mathrm{pH}$ of the dye solution, appreciably up to $\mathrm{pH} 7.0$ (Fig. 1). A further increase in dye adsorption between $\mathrm{pH} 7.0$ and 12.0 was insignificant. Since the optimum $\mathrm{pH}$ for dye adsorption by SD was found to be 7.0, this $\mathrm{pH}$ was used for further studies. As the $\mathrm{pH}$ increases, the charge density of the dye solution decreases, so that electrostatic repulsion between the positively charged dye molecule and the surface of the adsorbent is lowered, which results in an increase in the adsorption of the dye. The minimum removal of dye was thus found at $\mathrm{pH}$ 2, which is probably due to the $\mathrm{H}^{+}$ions competing favorably with the cationic groups of the dye molecule for adsorption sites on SD. Similar observations have been reported by other authors [22, 23]. The insignificant higher removal of the dye, observed at $\mathrm{pH}$ between 7.0 and 12.0, was noted to be accompanied by a drop in the original $\mathrm{pH}$ of the dye solution at adsorption equilibrium. This indicates a cationic exchange process between the dye molecule and the SD with the release of protons $\left(\mathrm{H}^{+}\right)$, as suggested in an earlier study [20, 24]. 


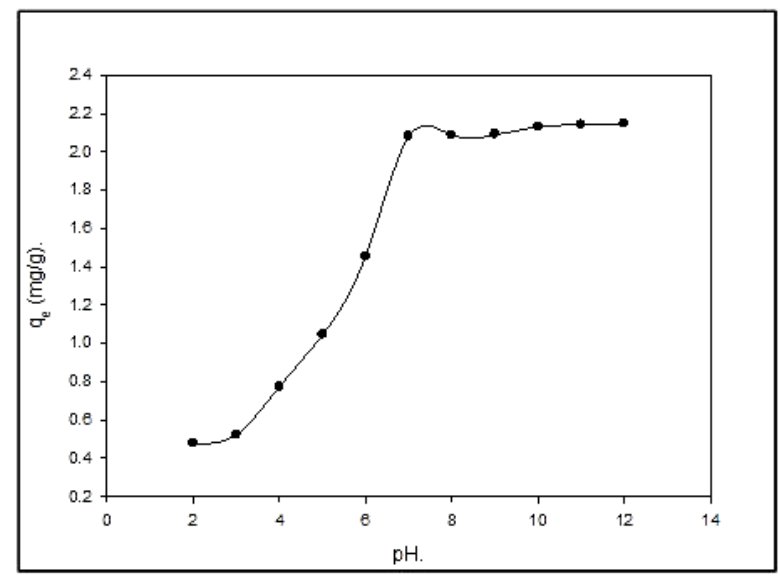

Fig. 1: Effect of $\mathrm{pH}$ on adsorption of $\mathrm{MG}$ solution by $\mathrm{SD}\left(\mathrm{V}=50 \mathrm{~mL}\right.$; Conc. $=5 \mathrm{mg} \mathrm{L}^{-1} ;$ Temp. $=15^{\circ} \mathrm{C} ; \mathrm{W}=100 \mathrm{mg}$; contact time $2 \mathrm{~h}$.).

\subsection{Effect of dosage of SD}

Variation of adsorbent dose showed that although increasing of SD dose in aqueous solution can result to increased dye removal. Fig. 2 shows the plot of \% of MG dye adsorption against the weight of adsorbent in mg. From the figure, it is observed that the percentage of adsorption is increases from 93.36 to $97.09 \%$ with increase in the adsorbent loading from 100 to $500 \mathrm{mg}$. This can be attributed to an increase in surface area of the sorbent, which in turn increases the binding sites. At higher SD dosage, there is a very fast adsorption on to the adsorbent surface that leads to improved uptake of the dye. However, with increasing SD load, the quantity of dye adsorbed on to the unit weight of SD gets reduced Fig. 2, thus causing a decrease in $\mathrm{q}_{\mathrm{e}}$ value with increasing SD loading. This may be due to complex interactions of several factors including availability of solute, electrostatic interactions and interference between binding sites, etc. The important factors being at high sorbent dosages the available dye molecules are insufficient to cover all the exchangeable sites on the sorbent, usually resulting in low dye adsorption.

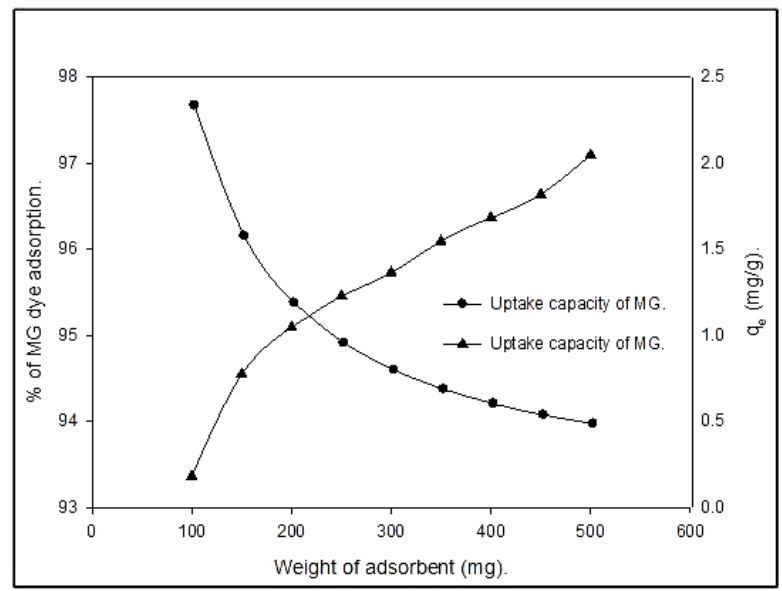

Fig. 2: Effect of weight of adsorbent on adsorption of MG solution by $\mathrm{SD}\left(\mathrm{V}=50 \mathrm{~mL} ;\right.$ Conc. $=5 \mathrm{mg} \mathrm{L}^{-1} ; \mathrm{pH}=7.0 ;$ Temp. $=15^{\circ} \mathrm{C}$; contact time $2 \mathrm{~h}$. $)$.

\subsection{Effect of temperature}

The effect of temperature on the adsorption capacity of dye was studied at $15,25,35,45$, and $55^{\circ} \mathrm{C}$ and the results were shown in Fig. 3. The results show that the adsorption capacity decreased from 2.25 to $1.90 \mathrm{mg} \mathrm{g}^{-1}$ with temperature increase from 15 to $55^{\circ} \mathrm{C}$. The equilibrium adsorption of the dye decreased with increasing temperature suggesting that adsorption of MG dye by SD was an exothermic process and the mechanism was mainly physical adsorption, dominant at lower temperatures. 


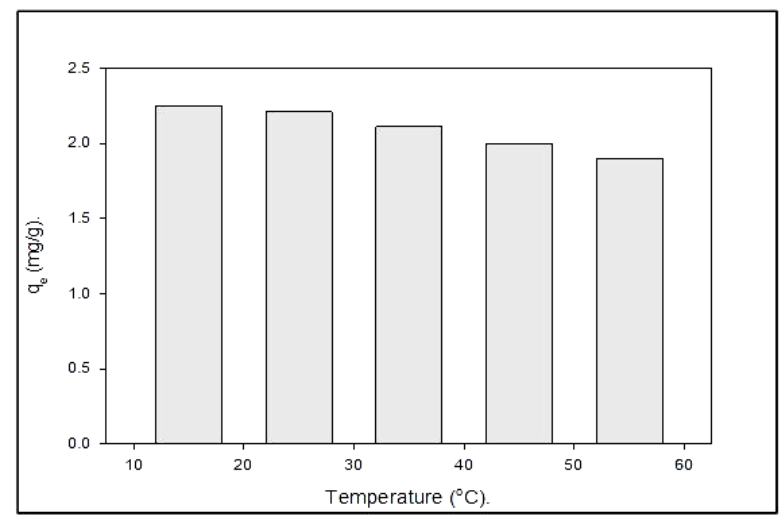

Fig. 3: Effect of temperature on adsorption of GM solution by $\mathrm{SD}\left(\mathrm{V}=50 \mathrm{~mL}\right.$; Conc. $=5 \mathrm{mg} \mathrm{L}{ }^{-1} ; \mathrm{pH}=7.0 ; \mathrm{W}=100 \mathrm{mg}$; contact time $2 \mathrm{~h}$. $)$.

\subsection{Adsorption isotherms modeling}

In order to optimize the design of adsorption system to remove MG dye from aqueous solutions, it is important to establish the most appropriate correlation for the equilibrium curves. The isotherms data were analyzed using three of the most commonly used equilibrium models, Langmuir and Freundlich.

The generalized adsorption isotherm has been used in linear form. A plot of the equilibrium data in form of $\ln \left[\left(\mathrm{q}_{\max } / \mathrm{q}_{\mathrm{e}}\right)-1\right]$ versus $\ln \mathrm{C}_{\mathrm{e}}$ gives isotherm constants, $\mathrm{K}$ is the saturation constant $\left(\mathrm{mg} \mathrm{L}^{-1}\right) ; \beta$ is the cooperative binding constant; $\mathrm{q}_{\max }$ is the maximum adsorption capacity of the adsorbent $\left(\mathrm{mg} \mathrm{g}^{-1}\right)$. The adsorption isotherms for MG dye on $\mathrm{SD}$ at different temperatures are presented in Fig. 4.

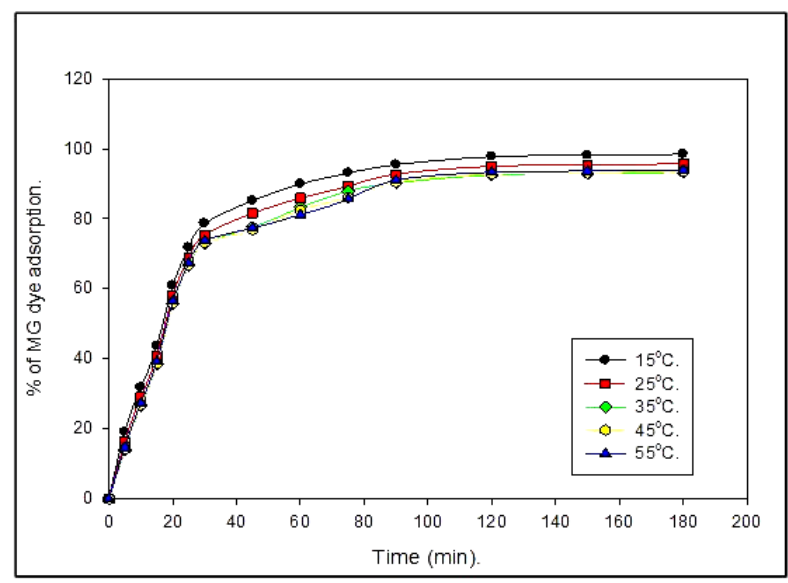

Fig. 4: Adsorption isotherms for MG dye onto SD under different temperatures. $\left(\mathrm{V}=50 \mathrm{~mL} ;\right.$ Conc. $\left.=5 \mathrm{mg} \mathrm{L}{ }^{-1} ; \mathrm{pH}=7.0 ; \mathrm{W}=100 \mathrm{mg}\right)$.

Figs. 5-7 show the plots of the linearized form. The Langmuir model is an ideal model for homogeneous monolayer adsorption. The best-fit values of the model parameters estimated from Eqs. (3-5) by linear regression analyses are listed in Table 1. Also are shown the correlation coefficients $\left(\mathrm{R}^{2}\right)$, which provide measure of model fitness.

A comparison of the experimental isotherms with the adsorption isotherm models showed that the Langmuir equation represented the poorest fit of experimental data $\left(\mathrm{R}^{2}=0.9594\right)$ at $15^{\circ} \mathrm{C}$ as compared to the other isotherm equations. It has been found that the best fitted isotherm equations at $15^{\circ} \mathrm{C}$ were Freundlich isotherm with $\mathrm{R}^{2}=0.9999$. The $\mathrm{n}$ parameter of the Freundlich equation $(0.9141<\mathrm{n}<0.9597)$ reveals adsorption sites with low energetically heterogeneity of this natural adsorbent [25].

Both $\mathrm{K}_{\mathrm{f}}$ and $\mathrm{n}$ reached their corresponding maximum values, at $15^{\circ} \mathrm{C}$. This implies that binding capacity reaches the highest value and the affinity between the sorbent and MG dye was also higher than other temperature values investigated (Table 1). The constant $\mathrm{b}$ represents affinity between the sorbent and sorbate, both $\mathrm{q}_{\max }$ and $\mathrm{b}$ increases from 61.31 to $158.98 \mathrm{mg} \mathrm{g}^{-1}$ and from 0.0028 to $0.0061 \mathrm{~L} \mathrm{mg}^{-1}$ respectively with decreasing temperature from 55 to $15^{\circ} \mathrm{C}$. The correlation coefficient of Freundlich isotherm equation $\left(\mathrm{R}^{2}=0.9999\right)$ is slightly higher than that obtained for other equations at $15^{\circ} \mathrm{C}$. 


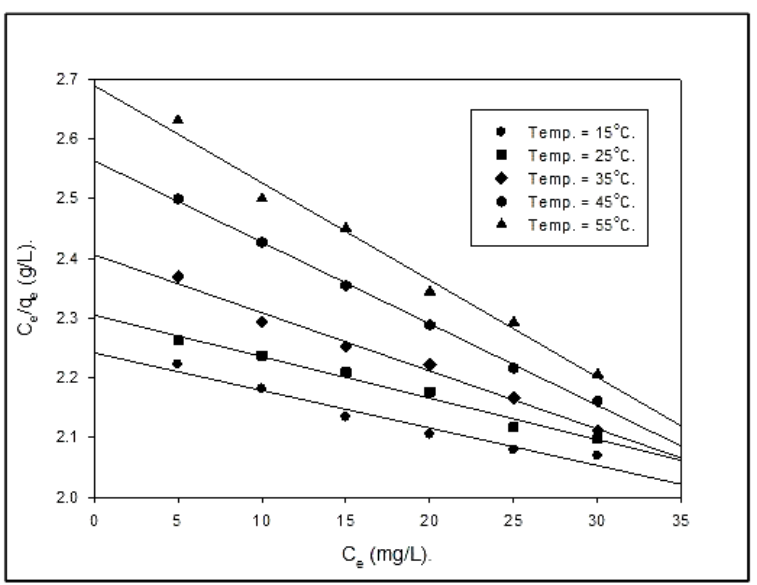

Fig. 5: Langmuir adsorption isotherm for $\mathrm{MG}$ on $\mathrm{SD}$ at various temperatures.

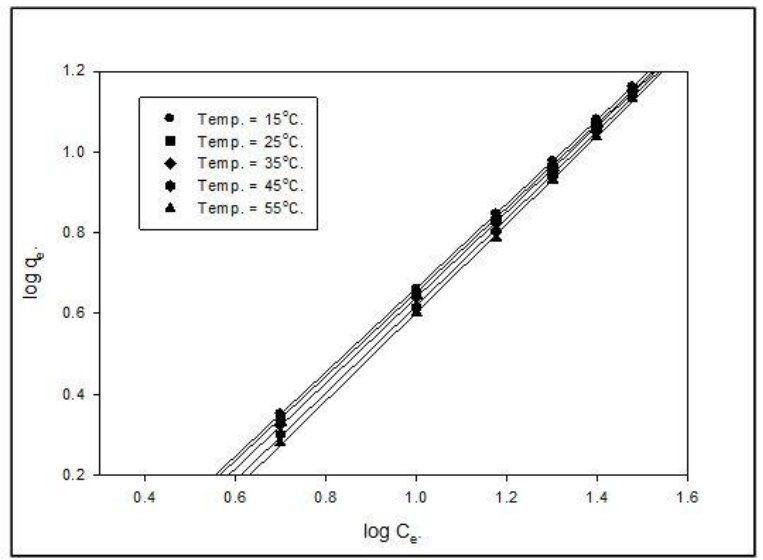

Fig. 6: Freundlich adsorption isotherm for MG on SD at various temperatures.

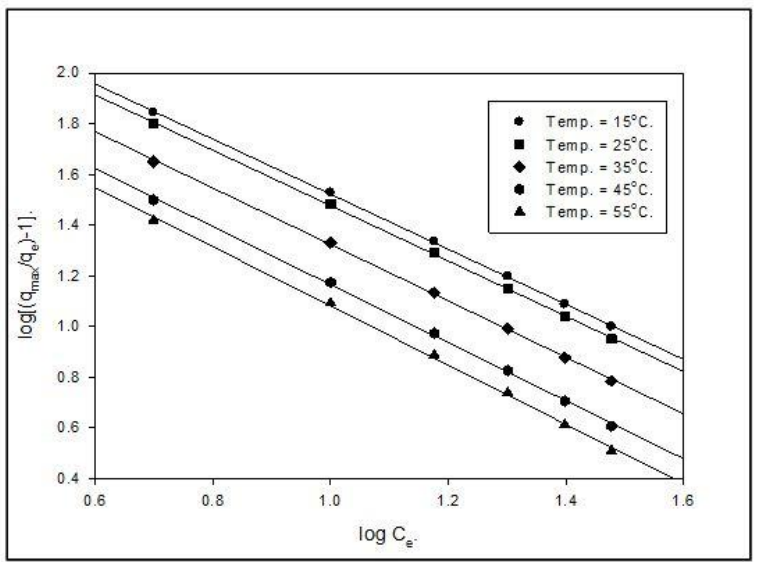

Fig. 7: Langmuir-Freundlich adsorption isotherm for MG on SD at various temperatures. 
Table 1: The thermodynamic parameters for MG adsorption on $(100 \mathrm{mg}) \mathrm{SD}$ at different temperatures.

\begin{tabular}{|c|c|c|c|c|c|}
\hline \multirow[t]{2}{*}{ Parameters } & \multicolumn{5}{|c|}{ Temperature $\left({ }^{\circ} \mathrm{C}\right)$. } \\
\hline & 15 & 25 & 35 & 45 & 55 \\
\hline \multicolumn{6}{|l|}{ Langmuir } \\
\hline $\mathrm{q}_{\max }\left(\mathrm{mg} \mathrm{g}^{-1}\right)$. & 158.98 & 143.88 & 102.71 & 73.15 & 61.31 \\
\hline $\mathrm{b}\left(\mathrm{L} \mathrm{mg}^{-1}\right)$ & 0.0061 & 0.0053 & 0.0040 & 0.0030 & 0.0028 \\
\hline $\mathrm{R}^{2}$ & 0.9594 & 0.9792 & 0.9862 & 0.9984 & 0.9847 \\
\hline \multicolumn{6}{|l|}{ Freundlich } \\
\hline n. & 0.9597 & 0.9588 & 0.9434 & 0.9251 & 0.9141 \\
\hline $\mathrm{K}_{\mathrm{f}}\left(\mathrm{mg} \mathrm{L}^{-1 \mathrm{n}} \mathrm{g}^{-1} \mathrm{~L}^{1 \mathrm{n}}\right)$. & 0.4189 & 0.4084 & 0.3805 & 0.3464 & 0.3231 \\
\hline $\mathrm{R}^{2}$ & 0.9999 & 0.9998 & 0.9998 & 0.9996 & 0.9996 \\
\hline \multicolumn{6}{|l|}{ Generalized isotherm } \\
\hline$\beta$. & 2.608 & 2.568 & 2.436 & 2.31 & 2.249 \\
\hline $\mathrm{K}\left(\mathrm{mg} \mathrm{L}^{-1}\right)$. & -1.086 & -1.091 & -1.113 & -1.145 & -1.168 \\
\hline $\mathrm{R}^{2}$ & 0.9997 & 0.9997 & 0.9995 & 0.9991 & 0.9987 \\
\hline
\end{tabular}

\subsection{Thermodynamic parameters of adsorption}

The adsorption isotherm data obtained at different temperatures were used to calculate potentially important thermodynamic properties, such as changes in the standard Gibbs free energy $\left(\mathrm{G}^{\circ}\right)$, standard enthalpy $\left(\mathrm{H}^{\circ}\right)$ and standard entropy $\left(\mathrm{S}^{\circ}\right)$. The Langmuir constant, $\mathrm{b}\left(\mathrm{L} \mathrm{mg}^{-1}\right)$, was used to calculate the change in the standard Gibbs free energy $\left(\mathrm{G}^{\circ}\right)$ according to the following equation:

$$
\Delta G^{\mathrm{o}}=-R T \ln b
$$

where $\mathrm{R}$ is the gas constant $(8.314 \mathrm{~J} / \mathrm{mol} \mathrm{K})$ and $\mathrm{T}$ the absolute temperature $(\mathrm{K})$. The changes in the standard enthalpy and entropy were obtained from the plot of $\ln \mathrm{b}$ vs. $1 / \mathrm{T}$; the equations are as follows:

$$
\Delta G^{\mathrm{o}}=\Delta H^{\mathrm{o}}-T \Delta S^{\mathrm{o}}
$$

From table 2 its clear that $\Delta \mathrm{G}^{\circ}$ values of $14070.10,14380.05,14109.21,13838.25$ and $13922.71 \mathrm{~J}^{-1}$ were obtained $^{-1}$ at $15,25,35,45$ and $55^{\circ} \mathrm{C}$, respectively. The $\Delta \mathrm{H}^{\circ}$ and $\Delta \mathrm{S}^{\circ}$ values obtained from the plot of $\ln \mathrm{b}$ vs $1 / \mathrm{T}\left(\mathrm{R}^{2}=0.9639\right)$ were $-0.001989 \mathrm{~J} \mathrm{~mol}^{-1}$ and $-48.8454 \mathrm{~J} \mathrm{deg}^{-1} \mathrm{~mol}^{-1}$, respectively, Fig. 8. The negative enthalpy value indicates that the MG adsorption process is exothermic, as the process usually favored by an decrease in temperature as this will activate the adsorption sites. The negative entropy value indicates the decreasing randomness at the solid/liquid interface during the adsorption process [26].

\begin{tabular}{|c|c|c|c|c|c|}
\hline $\begin{array}{c}\mathrm{T} \\
(\mathrm{K})\end{array}$ & $\begin{array}{c}\mathrm{b} \\
\left(\mathrm{L} \mathrm{mg}^{-1}\right)\end{array}$ & $\ln b$ & $\begin{array}{c}\Delta \mathrm{G}^{\circ} \\
\left(\mathrm{J} \mathrm{mol}^{-1}\right)\end{array}$ & $\Delta \mathrm{H}^{\circ}\left(\mathrm{J} \mathrm{mo}^{1-1}\right)$ & $\begin{array}{c}\Delta \mathrm{S}^{\circ} \\
\left(\mathrm{J} \mathrm{deg}^{-1} \mathrm{~mol}^{-1}\right)\end{array}$ \\
\hline 288 & $2.8055 \times 10^{-3}$ & -5.8762 & 14070.10 & \multirow[t]{5}{*}{-0.001989} & -48.8545 \\
\hline 298 & $3.0152 \times 10^{-3}$ & -5.8041 & 14380.05 & & -48.2552 \\
\hline 308 & $4.0466 \times 10^{-3}$ & -5.5099 & 14109.21 & & -45.8091 \\
\hline 318 & $5.3315 \times 10^{-3}$ & -5.2341 & 13838.25 & & -43.5165 \\
\hline 328 & $6.0632 \times 10^{-3}$ & -5.1055 & 13922.71 & & -42.4473 \\
\hline
\end{tabular}

Table 2: The thermodynamic parameters for MG adsorption on $(100 \mathrm{mg}) \mathrm{SD}$ at different temperatures. 


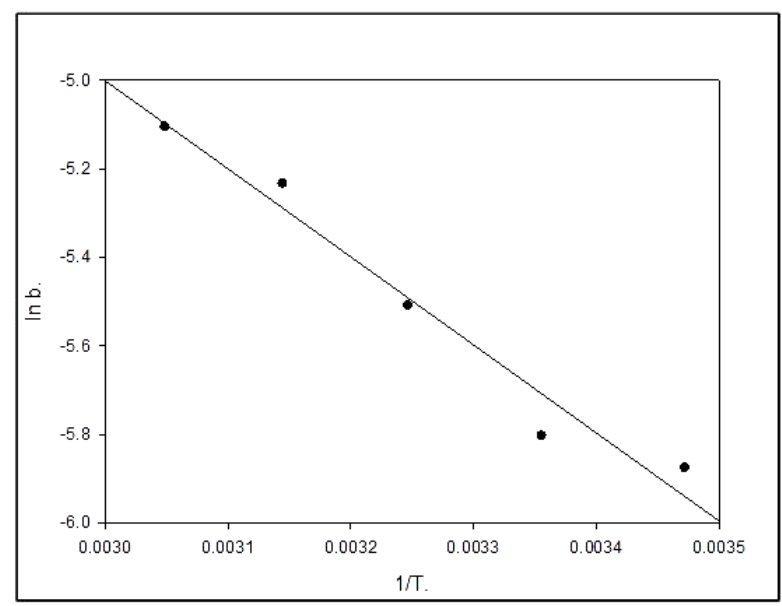

Fig. 8: Van't Hoff plot for the adsorption of MG dye onto SD at various temperatures.

\subsection{Adsorption kinetics studies}

Kinetics of dye adsorption governs the rate that determines the residence time and it is one of the important characteristics defining the efficiency of an adsorbent. The kinetic profiles of dye adsorption onto the SD composite were inspecting in this section.

\subsubsection{Effect of contact time}

It can be observed from Fig. 9 that the process was found to be very rapid initially, and a large fraction of the total amount of dye was removed within a few minutes. Also, it is clear that the percentage dye adsorption increased with time and, at some point in time, reached a constant value where no more dye was removed from the solution. At this point, the amount of dye being adsorbed onto the adsorbent was in a state of dynamic equilibrium with the amount of dye desorbed from the adsorbent. The time required to attain this state of equilibrium was termed the equilibrium time and the amount of dye adsorbed at the equilibrium time reflected the maximum dye adsorption capacity of the adsorbent under these particular conditions [27]. The results showed that the equilibrium states were attained at 180 min for the different studied dye concentrations.

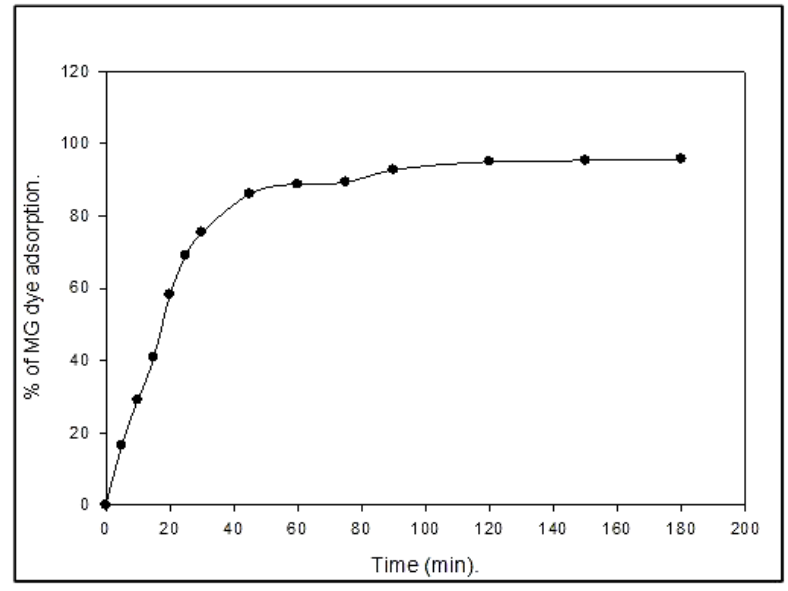

Fig. 9: Effect of time on adsorption of $\mathrm{MG}$ solution by $\mathrm{SD}\left(\mathrm{V}=50 \mathrm{~mL}\right.$; Conc. $=5 \mathrm{mg} \mathrm{L}{ }^{-1} ; \mathrm{pH}=7.0 ;$ Temp. $=15^{\circ} \mathrm{C}$; W $\left.=500 \mathrm{mg}\right)$.

\subsubsection{Effect of initial dye concentration}

Adsorption of MG dye onto SD was measured at the equilibrium time for six different initial concentrations at sorbent dosage of $500 \mathrm{mg}$ of dye solution. The effect of initial dye concentration on the equilibrium adsorption capacity and percentage adsorption are shown in Fig. 10. From the figure, it is evident that the percentage of adsorption of dye 
adsorbed at equilibrium increases from 95 to $98 \%$ for an increase in initial dye concentration from 5 to $30 \mathrm{mg} \mathrm{L}^{-1}$. Where a higher initial dye concentration provides an important driving force to overcome all resistances of the dye between the aqueous and solid phases, thus increasing the rate of adsorption that by its rule increase the adsorption capacity for sorbent [28]. On the other hand, the percentage adsorption shows a decreasing trend as the initial concentration of the dye is increased. At lower concentrations, all sorbate ions present in the adsorption medium could interact with the binding sites, hence higher percentage adorption results. At higher concentrations, because of the saturation of the adsorption sites, the percentage adsorption of the MG dye by SD shows a decreasing trend [28]. These results accord well with the findings of other investigators $[29,30]$.

\subsection{Kinetics of adsorption process}

The principle behind the adsorption kinetics involves the search for a best model that well represents the experimental data. Several kinetic models are available to understand the behavior of the adsorbent. In the present investigation, the adsorption data were analyzed using two simplest kinetic models, the pseudo-first order and pseudo-second order kinetic models Figs. 10-12.

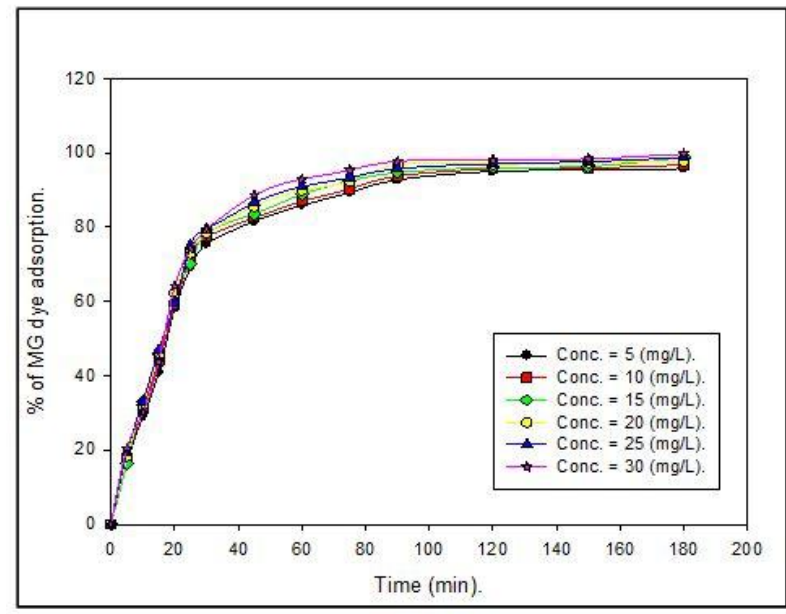

Fig. 10: Effect of initial concentration on adsorption of $\mathrm{MG}$ solution by $\mathrm{SD}\left(\mathrm{V}=50 \mathrm{~mL} ; \mathrm{pH}=7.0 ;\right.$ Temp. $\left.=15^{\circ} \mathrm{C} ; \mathrm{W}=500 \mathrm{mg}\right)$.

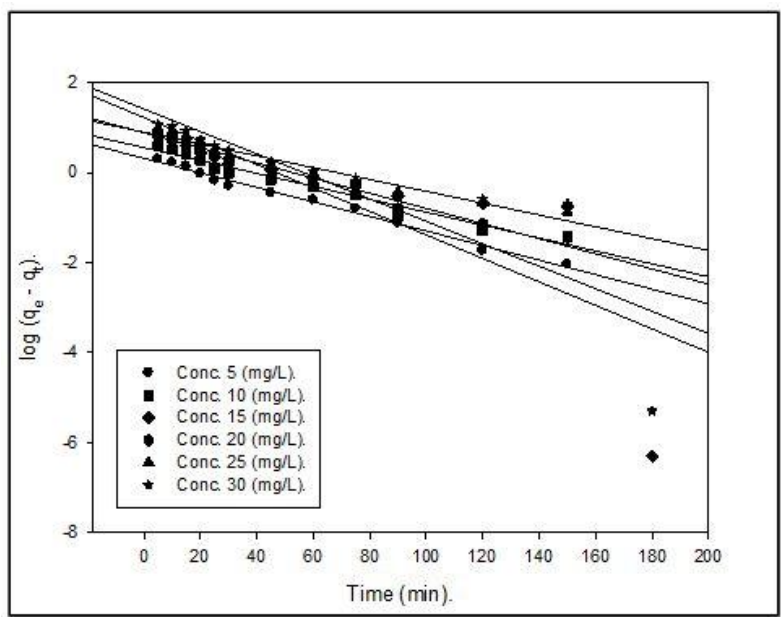

Fig. 11: Pseudo-first order plots for different initial dye concentrations removal using $\mathrm{SD}\left(\mathrm{V}=50 \mathrm{~mL} ; \mathrm{pH}=7.0 ; \mathrm{Temp} .=15^{\circ} \mathrm{C} ; \mathrm{W}=500 \mathrm{mg}\right)$. 


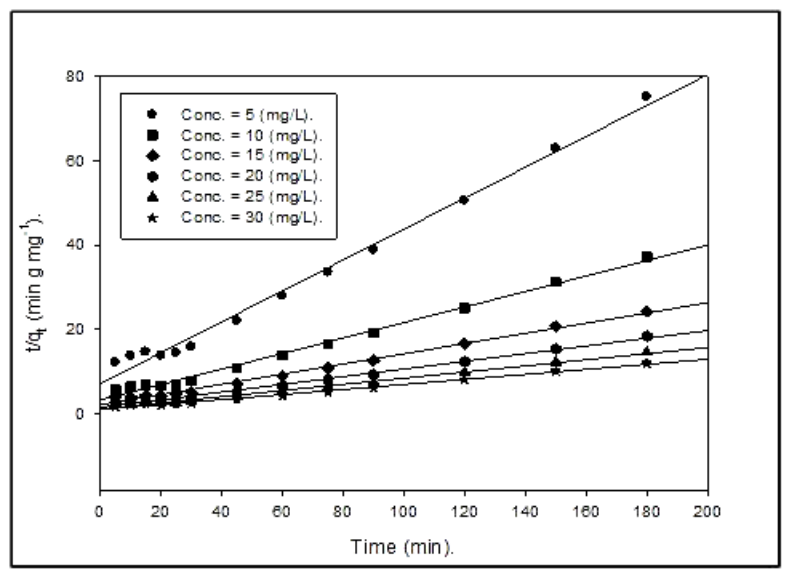

Fig. 12: Pseudo-second order plots for different initial dye concentrations removal using $\mathrm{SD}\left(\mathrm{V}=50 \mathrm{~mL} ; \mathrm{pH}=7.0 ; \mathrm{Temp} .=15^{\circ} \mathrm{C} ; \mathrm{W}=500 \mathrm{mg}\right)$.

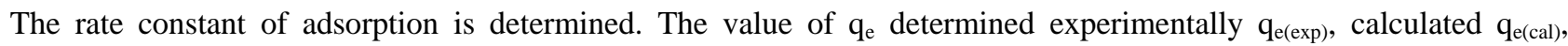
correlation coefficient together with the adsorption rates $\mathrm{k}_{1}$ and $\mathrm{k}_{2}$ are shown in Table 3 . The correlation coefficients for the first order kinetic model were determined and compared with that of second order kinetic model. It is seen that the correlation coefficient of first order kinetic are lower than in the case of second order kinetic model (Table 3). This shows that kinetics of MG dye adsorption by SD are better described by pseudo-second order kinetic model rather than pseudo-first order. The linearity of the plot also shows the applicability of the pseudo-second order kinetic model, which has average regression coefficient of $\mathrm{R}^{2}$ 0.9926. Also, $\mathrm{q}_{\mathrm{e}(\mathrm{cal})}$ using pseudo-second order kinetic model is in par with $\mathrm{q}_{\mathrm{e}(\exp )}$ which has been obtained experimentally and the average percentage error between the experimental and predicted values was calculated.

Table 3: Rate constants for kinetic models at various initial concentrations.

\begin{tabular}{|c|c|c|c|c|c|c|c|c|c|}
\hline \multirow{2}{*}{$\begin{array}{c}\text { Initial } \\
\text { concentrat } \\
\text { ion }(\mathrm{mg} / \mathrm{L})\end{array}$} & \multirow{2}{*}{$\begin{array}{c}q_{\mathrm{e}(\exp )} \\
(\mathrm{mg} / \mathrm{g})\end{array}$} & \multicolumn{4}{|c|}{ Pseudo-first order rate constants } & \multicolumn{4}{|c|}{ Pseudo-second order rate constants } \\
\hline & & $\mathbf{k}_{1}\left(\min ^{-1}\right)$ & $\begin{array}{c}\mathrm{q}_{\mathrm{e}(\mathrm{cal})} \\
(\mathrm{mg} / \mathrm{g})\end{array}$ & $\mathbf{R}^{2}$ & $\varepsilon(\%)$ & $\begin{array}{c}\mathbf{k}_{2} \\
(\mathrm{~g} / \mathrm{mg} \\
\mathrm{min})\end{array}$ & $\begin{array}{c}\mathrm{q}_{\mathrm{e}(\mathrm{cal})} \\
(\mathrm{mg} / \mathrm{g})\end{array}$ & $\mathbf{R}^{2}$ & $\varepsilon(\%)$ \\
\hline 5 & 2.3932 & 0.01617 & 2.2629 & 0.9892 & 5.4450 & 0.3664 & 2.3781 & 0.9915 & 0.6303 \\
\hline 10 & 4.8364 & 0.01436 & 4.4716 & 0.9760 & 7.5418 & 0.1836 & 4.8063 & 0.9931 & 0.6225 \\
\hline 15 & 7.4045 & 0.0114 & 6.4532 & 0.9259 & 12.8472 & 0.1209 & 7.3589 & 0.9929 & 0.6161 \\
\hline 20 & 9.7727 & 0.01682 & 9.2994 & 0.9668 & 4.8426 & 0.0912 & 9.7122 & 0.9930 & 0.6194 \\
\hline 25 & 12.3409 & 0.01310 & 11.1733 & 0.9561 & 9.4608 & 0.0728 & 12.2650 & 0.9940 & 0.6147 \\
\hline 30 & 14.9591 & 0.01323 & 13.5766 & 0.9182 & 9.2421 & 0.0597 & 14.8668 & 0.9914 & 0.6171 \\
\hline
\end{tabular}

\section{Conclusions}

The present study suggests that SD can be effectively used as a cost effective adsorbent for removal of MG from water and wastewater, in general. Batch adsorption studies show that removal is dependent upon process parameters like $\mathrm{pH}$, temperature, dosage of SD, concentration of dye and contact time. Adsorption followed pseudo-second-order kinetics equation. The experimental equilibrium adsorption data obtained from batch studies at optimized conditions fit well to Freundlich adsorption isotherm equation. The values of $\mathrm{n}$ have been found to be $\approx 1$ which suggest favorable adsorption.

\section{References}

[1] O. Gulnaz, A. Kaya, F. Matyar, B. Arikan, Sorption of basic dyes from aqueous solution by activated sludge, Journal of Hazardous Materials. 108(3) (2004) 183-188.

[2] W.T. Tsai, C.Y. Chang, M.C. Lin, S.F. Chien, H.F. Sun, M.F. Hsieh, Adsorption of acid dye onto activated carbons prepared from agricultural waste bagasse by $\mathrm{ZnCl} 2$ activation, Chemosphere. 45(1) (2001) 51-58. 
[3] K. Santhy. P. Selvapathy, Removal of reactive dyes from wastewater by adsorption on coir pith activated carbon, Bioresource Technology. 97(11) (2006) 1329-1336.

[4] T. Santhi, S. Manonmani, Removal of Methylene Blue from Aqueous Solution by Bioadsorption onto Ricinus communis Epicarp Activated Carbon, Chemical Engineering Research bulletin. 13 (2009) 1-5.

[5] S. Wang, Z.H. Zhu, A. Coomes, F. Haghseresht, G.Q. Lu, The physical and surface chemical characteristics of activated carbons and the adsorption of methylene blue from wastewater, J. Colloid Interface Sci. 284 (2005) 440-446.

[6] A. Gurses, C. DogarC, M. Yalcin, M. Acikyildiz, R. Bayrak, S. Karaca, The adsorption kinetics of the cationic dye, methylene blue, onto clay, J. Hazard. Mater. 131 (2006) 217-228.

[7] M.M. Alexandro, L. Vargas Andre, H. Cazetta Marcos, L. Kunita Tais, C. Silva Vitor Almeida, Adsorption of methylene blue on activated carbon produced from flamboyant pods (Delonix regia): Study of adsorption isotherms and kinetic models, Chemical Engineering Journal. 168 (2011) 722-730.

[8] E.N. El Qada, S.J. Allen, G.M. Walker, Adsorption of methylene blue onto activated carbon produced from steam activated bituminous coal: a study of equilibrium adsorption isotherm, Chem. Eng. J. 124 (2006) 103-110.

[9] S. Altenor, B. Carene, E. Emmanuel, J. Lambert, J.J. Ehrhardt, S. Gaspard, Adsorption studies of methylene blue and phenol onto vetiver roots activated carbon prepared by chemical activation, J. Hazard. Mater. 165 (2009) 1029-1039.

[10] M.M. Ahmad AL, Loh, J.A. Aziz, Preparation and characterization of activated carbon from oil palm wood and its evaluation on methylene blue adsorption, Dyes Pigments. 75 (2007) 263-272.

[11] K.G. Bhattacharyya, A. Sharma, Kinetics and thermodynamics of methylene blue adsorption on Neem (Azadirachta indica) leaf pow der, Dyes Pigments. 65 (2005) 51-59.

[12] K. Singh, M. Talat, S. Hasan, Removal of lead from aqueous solutions by agricultural waste maize bran, Bioresource Technology. 97(16) (2006) 2124-2130.

[13] [13] K. Vijayaraghavan, K. Palanivelu, M. Velan, Biosorption of copper(II) and cobalt(II) from aqueous solutions by crab shell particles, Bioresource Technology. 97(12) (2006) 1411-1419.

[14] K.V. Kumar, Optimum sorption isotherm by linear and nonlinear methods for malachite green onto lemon peel, Dyes and Pigments. 74(3) (2007) 595-597.

[15] N. Pramanpol, N. Nitayapat, Adsorption of Reactive Dye by Eggshell and Its Membrane, The Kasetsart Journal. 40(SI) (2006) 192-197

[16] I. Langmuir, The adsorption of gases on plane surfaces of glass, mica, and platinum, J. Am. Chem. Soc. 40 (1918) 1361-1403.

[17] H.M.F. Freundlich, Uber die adsorption in losungen, Z. Physikalische Chem. (Leipzig). 57(A) (1906) 385-470.

[18] R. Sips, On the structure of a catalyst surface, J. Chem. Phys. 16(5) (1948) 490-495.

[19] S. Lagergren, Zur theorie der sogenannten adsorption gelosterstoffe, Kungliga Svenska Vetenskapsakademiens, Handlingar. 24 (1898) 1-39.

[20] A. Saeed, M. Sharif, I. Iqbal, Application potential of grapefruit peel as dye sorbent: Kinetics, equilibrium and mechanism of crystal violet adsorption, Journal of Hazardous Materials. 179 (2010) 564-572.

[21] Y.S. Ho, G. Mackay, Sorption of dye from aqueous solution by peat, Chem. Eng. J. 70 (1998) 115-124.

[22] M. Ramakrishnan, S. Nagarajan, Utilization of waste biomass for the removal of basic dye from water, World Appl. Sci. J. 5 (2009) 114-121.

[23] P. Monash, G. Pugazhenthi, Adsorption of crystal violet dye from aqueous solution using mesoporous materials synthesized at room temperature, Adsorption. 15 (2009) 390-405.

[24] Y.S. Ho, Effect of pH on lead removal from water using tree fern as the sorbent, Bioresour. Technol. 96 (2005) $1292-1296$.

[25] M.M. Davila-Jimenez, M.P. Elizalde-Gonzalez, A.A. Pelaez-Cid, Adsorption interaction between natural adsorbents and textile dyes in aqueous solution, Colloid Int. Sci. 254A(1-3) (2005) 107-114.

[26] N. Tewari, P. Vasudevan, B.K. Guha, Study on biosorption of Cr(VI) by Mucor hiemalis, Biochemical Engineering Journal. 23 (2005) 185192.

[27] P. Waranusantigula, P. Pokethitiyooka, M. Kruatrachuea, E.S. Upatham, Kinetics of basic dye (methylene blue) biosorption by giant duckweed (Spirodela polyrrhiza), Environ. Pollut. 125 (2003) 385-392.

[28] R. Aravindhan, N.N. Fathima, J.R. Rao, B.U. Nair, Equilibrium and thermodynamic studies on the removal of basic black dye using calcium alginate beads, Colloids Surf. A: Physicochem. Eng. Aspects. 299 (2007) 232-238.

[29] I.D. Mall, S.N. Upadhyay, Studies on treatment of basic dyes bearing wastewater by adsorptive treatment using flyash, Ind. J. Environ. Health. 92 (1998) 177-188.

[30] G. Mckay, Application of surface diffusion model to adsorption of dyes on bagasse pith, Adsorption. 4 (1998) 361-372. 